\title{
Relationship of school climate dimensions and teachers' commitment
}

\author{
Cammellia Othman ${ }^{1}$, Jati Kasuma ${ }^{2, *}$ \\ ${ }^{1}$ Faculty of Education, Universiti Teknologi MARA, Kota Samarahan, Sarawak, Malaysia \\ ${ }^{2}$ Faculty of Business Management, Universiti Teknologi MARA, Kota Samarahan, Sarawak, Malaysia
}

\section{A RT I C LE IN F O}

Article history:

Received 6 November 2016

Received in revised form

19 January 2017

Accepted 19 January 2017

Keywords:

School climate

Teachers commitment

\begin{abstract}
A B S T R A C T
This study aims to investigate the relationships between school climate and teachers' commitment with the assumption and predictability of key dimensions of school climate in relation to Collegial Leadership, Teacher Professionalism, Academic Press and Institutional Vulnerability towards teacher commitment. The population of this study consisted of teachers from 5 National Primary Schools in the Sri Aman district with 131 respondents has been selected as a sample. Result revealed that the level of school climate and teachers' commitment of the selected 5 primary schools is in moderate level. The school climate dimensions were positively correlated with the teachers' commitment and finally Achievement Press made a significant contribution to teachers' commitment. Future research and recommendation also discussed at the end of the paper.
\end{abstract}

(c) 2017 The Authors. Published by IASE. This is an open access article under the CC BY-NC-ND license (http://creativecommons.org/licenses/by-nc-nd/4.0/).

\section{Introduction}

As an impact of globalization, quality of education becomes the fundamental goal of Malaysian education reforms due to unsatisfactory amount of the right human capital. According to Fredriksson (2004), teachers have the responsibilities to rise up the school success because they have the actual power to make a change in students' capital development during teaching and learning process. Thus, teachers' commitment is a critical aspect in ensuring the success of education development and school success (Razak et al., 2009) because they will highly perform their duties as if the school belonged to them (Joffres and Haughey, 2001). Nevertheless, due to stressful profession, teachers tend to show low organizational commitment (Williams and Ritter, 2010). Conversely, stress is not the only reason for teacher's low organizational commitment. Teachers' traditional role had increased to become more complicated (Bartlett, 2004). Ross and Normah (2011) explained that teachers have too many obligations towards parents; education reform and principal which results in work overload (Stoddard and Kuhn, 2008). Furthermore, Leithwood and

\footnotetext{
* Corresponding Author.

Email Address: jati@sarawak.uitm.edu.my (J. Kasuma)

https://doi.org/10.21833/ijaas.2017.03.015

2313-626X/C 2017 The Authors. Published by IASE.

This is an open access article under the CC BY-NC-ND license

(http://creativecommons.org/licenses/by-nc-nd/4.0/)
}

McAdie (2007) reported that not only overburden has reduced teachers' organizational commitment, but also teachers poor relationship with the principal.

Organizational climate is viewed as the estimation of an individual's relationship with bosses and workers in the workplace. Organizational climate is the internal characteristics of a school that recognizes one school from another school (Hoy et al., 2002). Organizational climate influences the behavior of its members. A school's organizational climate varies from open to closed (Halpin and Croft, 1963). High morale can be classified as open. Teachers work well together without squabbling and grumbling. They are not troubled around busy work or routine reports. Instructors get a lot of occupation fulfilment and they have the incentive to keep the organization moving. Educators are pleased to be connected with the school organization. Hoy et al. (2006) portrayed the conclusion that school climate is straightforwardly identified with school results. The investigation of climate is targeted at understanding its effect on outcomes in order to formulate strategies for change. Hoy et al. (1991) stated that school climate is moderately persisting nature of a school's surroundings that is experienced by all school staffs. These characteristics make a distinction one school from another and influence the behavior of its staffs. Firestone and Pennell (1993) said that committed teachers would show better behavior such as stable, strong, enduring psychological ties to their schools, their students and their subject areas. 
Teacher's commitment may be directed towards a number of entities; for example, to student's success, to the occupation of teaching, to the school as an organization or to specific programs. From these, the teachers' commitment to their schools as organizations served as the focus of the present study. Schools can become efficient when there are committed teachers. Thus, creating a positive school climate can be a great help to make teachers committed. School heads and administrators need to know the factors that are related to school climate. A positive school culture is the critical first step administers need to encourage. Thus, the school management should be responsible in playing a vital role in creating a good working environment for the teachers. Hence, it would lead to improvement of students' behavior and academic achievement. Climate of the school should be in a state that is conducive to ensure that students and teachers feel comfortable to be in school, thus allowing the teaching and learning process to go smoothly.

In addition, a positive school climate has also become part of the claims in the educational arena to create a perfect society in terms of physical, emotional, spiritual, intellectual and personality in line with the National Education Philosophy. Therefore, this research will attempt to study the predictability of the key dimensions of school climate in related to headmaster and teachers behavior.

With many experiences in educating elementary school, the researcher has become gradually more interested and aware of the way in which school climate influences teachers' motivation, satisfaction and dedication in their work. Having taught in different grades and having the opportunity to explore the work of teachers and the impact they have within schools regarding various school attributes towards their commitment and job satisfaction, the researcher strongly believes that school climate has a major effect on teachers' commitment. In order to achieve these goals, teachers' potential must be realized to the maximum. Thus, objectives of this research are to investigate the relationship between the four dimensions of school climate as well as teachers commitment and finally to investigate the significant predicator of school climate dimensions for teachers' commitment.

\section{Literature review}

\subsection{Organizational/School climate dimensions}

Halpin and Croft (1963) described Organizational Climate as the personality of the school and conceptualized it along continuum from open to close. On the other hand, Anderson (1982) uses the analogy 'Personality is to the individual what 'climate' is to the 'organization' to conceptualize what the school climate is. It further explains the four variables that appear to be tied to the total environmental quality which are ecology, milieu, social system and culture. It also explains milieu is the characteristics of persons or groups within the school environment. Several factors of this variable effect the school environment. For example, it is suggested teacher's stability (teacher characteristics) is important. Accordingly, the author reports teacher's attitudes toward work (teacher morale) correlate with the school environment. There are several factors in the social system variable that effect school environment, such as shared teacher decision-making, good communication and teacher-student relationships. Culture is the final variable and includes these three important factors namely teacher commitment, expectations, praise and rewards. The prior studies of organizational climate focused on health and openness. Although health and openness are different things, they do overlap. The evaluation of a school supposed open is most likely healthy and in turn a healthy school is most often an open one (Hoy et al., 2002). In an effort to evaluate climate by combining health and openness, Hoy et al. (2002) developed the work of Hoy et al. (1998) to build the Organizational Climate Index (OCI). The OCI coverings four dimensions: professional teacher, achievement press, collegial leadership and institutional vulnerability. The collegial leadership subtest emphasizes how the principal treats teachers as professional colleagues and the openness of the principal. The collegial leadership subtest also looks at the principal's clear expectation and standards for the teacher. The teacher professionalism subtest emphasizes on the openness of the teacher-toteacher collaboration. The academic press subtest indicates the relationship between the school and academic success of the students. Finally, the institutional vulnerability subtest indicates the relationship between the school and the community.

\subsection{Collegial leadership}

Hoy et al. (2002) defined collegial leadership as the principal behavior pointed toward meeting both social needs of the faculty and achieving the goals of the school. The principal treats teacher as colleagues, egalitarian, is open and friendly but at the same time sets clear teacher's expectancies and standards of performance. Current research has additionally suggested that the principal's influence has an indirect effect on learning and is mediated by their interactions with others, situational events and the organizational and cultural factors of the school (Hallinger and Heck, 1998; Hoy et al., 2006; Leithwood et al., 2004). Maslowski (2001) further stated that an association exits between leadership values and behaviours and school culture and that different school cultures can be identified with different consequences for student's outcomes. Furthermore, research studies exploring the indirect effect of principal leadership on student outcomes have suggested that educational leadership is related to the organization and culture of the school, which is related in turn to student achievement (Witziers et 
al., 2003). Researchers have found that certain behaviors of principals such as being competent managers, promoting professional growth and curriculum development, and empowering teachers all encourage teachers to trust their principals. They also discovered that the most important factor leading to a teacher trusting a principal is the principal being kind to the teacher. An effective principal realizes that pride in the school has its origins in achievement on several levels such as personal, classroom and school (Sweeney, 1992). When principals involve teachers in school decisions, it will lead to a greater faculty effort, persistence and commitment (Hoy et al., 2002).

\subsection{Teacher professionalism behavior}

Hoy et al. (2002) marked Professional Teacher Behavior is with respect for colleague competence, commitment to students, autonomous judgement and mutual cooperation and support of colleagues. These researchers have found that professional teacher behavior is positively related to the organizational commitment of teachers. Teachers are more likely to be committed to a school. At the same time, they work collaboratively and support one another. Prior research made by Hoy and Woolfolk (1990) and Smith et al. (2009) supported a strong connection between professional teacher behavior and teacher commitment. Thus, Smith et al. (2009) studied is significant because the OCI was used in the study.

\subsection{Achievement press}

Achievement press explains a school that sets high, but achievable goals, academically and standards. Students persist, strive to accomplish and are respected by both students and teachers for their academic achievement. Parents, teachers, and the principal all exert pressure for high standards and school development.

Regarding the above, two studies were made that combined the OHI dimensions of academic emphasis, resource support and principal influence to form a second-order factor, academic press. Firstly, a study in 97 high schools (Hoy et al., 2002) added collective teacher efficacy as a variable and examined the relationships among academic press, collective teacher efficacy and student achievement. Researchers also found that academic press only indirectly predicted students' achievements through collective teacher efficacy.

Then, in 146 elementary schools, instructional leadership (Alig-Mielcarek, 2003) was added as a variable and the relationships among academic press, instructional leadership and student achievement was examined. Findings included positive correlations between academic press and all aspects of instructional leadership. In addition, academic press significantly predicted reading achievement $(\beta=0.16, \mathrm{p}<0.01)$ and math achievement $(\beta=0.23, \mathrm{p}<0.01)$. Instructional leadership indirectly worked through an academic press to predict student achievement. Meanwhile, Hoy (2003) measured the climate of 97 high schools in Ohio. The aim of their study was to measure the relationship between organizational climate and faculty trust. The schools were diverse in terms of geographic areas in such that they were urban, suburban and rural schools. The design of the study was quantitative. The Organizational Climate Index was used to measure four general dimensions of school climate. The four dimensions studied were institutional vulnerability, collegial leadership, professional teacher behavior and achievement press. The research findings indicated that achievement press as one of climate characteristics promotes trust in parents and students, which leads to higher commitment to achieving excellence. They also discovered that when students, teachers and the school value academic achievement, they demand for higher standards and more improvement.

\subsection{Institutional vulnerability}

Institutional vulnerability is the extent to which the school is vulnerable to a few vocal parents and citizen groups. High vulnerability suggests that both principals and teachers are unprotected and put on the defensive level (Hoy et al., 2002). Despite a suspected relationship, previous research fails to support this theoretical link. The research (Hoy et al., 1991) does support a link to student's achievement, and the collection of all the subtests collectively frames this study.

The previous study showed that Institutional vulnerability is negatively related to the organizational commitment of teachers. A school that can be influenced by a little group of influential parents or community members can expect a low level of teacher commitment. This is because teachers have little reason to believe they will be supported or protected from these parties.

\subsection{Teachers commitment}

Teacher's commitment is central in improving teacher performance and student learning and to reduce teacher's turnover or intentions to leave the profession (Hausman and Goldring, 2001). They conducted a study on teacher commitment in the United States which was aimed at comparing levels of teachers' commitment in magnet, referring to schools which have teachers who chose where they want to work and non-magnet schools is that schools with teachers who were assigned.

The results showed that magnet teachers rated their commitment higher than their peers in nonmagnet schools. The magnet schools were characterized by higher levels of teacher autonomy, while the non-magnet teachers reported greater goal congruence. The results showed that teachers had a lower commitment in non-magnet schools serving higher proportions of poor students. Thus, these results show that teachers' level of professional 
commitment can be influenced by the nature or type of school they work for. Highly affective committed teachers could also be a good instructional leader in the classroom because they are able to master the contents of the subjects that they once taught, thus they would demonstrate effective teaching. Additionally, teachers with a high level of affective commitment might always monitor the students' work, able to control the classroom and involved in extra-curricular activities because they tend to demonstrate organizational citizenship behaviour. On the other hand, affective commitment, normative commitment and continuance commitment provide similar positive outcome (Allen and Meyer, 1996). The characteristics of a school also affect the level of commitment as identified by Riehl and Sipple (1996). Teachers getting administrative support are more likely to be committed to the school's objectives and values.

Teachers correlated with an orderly school have a higher level of professional commitment. Another characteristic accompanying with commitment is classroom autonomy for teachers. Peer support is also a key element in teacher's commitment (Singh and Billingsley, 1998). Positive school climate has ended up being the effective rhetoric and is advocated by educational practitioners and reformers as a specific means for enhancing student's achievement (Smith et al., 2001). Hoy et al. (1991) provided some evidence that organizational climate is related to other important variables such as student's performance and trust.

\section{Methodology}

Framework for this study involves the four subtests of the OCI and teacher's commitment as measured by the OCQ. The variables of this study are created from the four variables that include the OCI. The four subtests explained previously are: achievement press, collegial leadership, professional teacher behavior, and institutional vulnerability. Each of these four theoretically provides a link to a teacher's commitment. The elementary teachers who participated in this study were teachers from five primary schools.

The teachers had completed at least 1 year of teaching to ensure the effects of school climate on job commitment. All these five schools are National Schools (SK). These five primary schools have a total number of 140 teachers. This data was obtained from the Education Office and a total of 131 respondents was completed the questionnaires. The sampling technique used for this study was nonprobability sampling.

The questionnaire was chosen because of its comparatively low cost, small biasing error, accessibility as well as anonymity. An approval letter from Education Planning and Research Department (EPRD) and Jabatan Pelajaran Negeri Sarawak (JPNS) was first obtained to get permission to conduct this study.

\section{Results and discussion}

\subsection{Profile of respondent}

Most teachers in primary schools (Table 1) were aged between 26 to 34 years (50\%), followed by teachers aged between 35 to 44 years (39\%), then teachers aged between 41 years to over (36\%) and then teachers with the age less than 25 years $(6 \%)$. Iban ethnic which is $79 \%$ of them, followed the Malay (30\%), Chinese (8\%), Bidayuh (13\%) and others (1\%). Additionally, in terms of educational level, majorities of the teachers hold a Bachelor's Degree which is $88(67.2 \%)$ and 43 teachers (32.8\%) hold Diploma Certificate. For working experiences only 6 teachers work less than one year in their respective schools (4.6\%), followed by 24 teachers working for one to five years (18.3\%), majority teachers working in their respective schools between six to ten years which is 65 teachers (34.9\%), 27 teachers working for 11 to 15 years $(20.6 \%)$ and 36 teachers had served more than 15 years $(27.5 \%)$. Finally, most of the teachers are subject teacher which is 104 of them (79.4\%), following with 21 senior teachers (16\%) and 6 teachers as a head of teacher $(6 \%)$.

Table 1: Demographic profile

\begin{tabular}{|c|c|c|}
\hline & Frequency & Percent \\
\hline \multicolumn{3}{|c|}{ Gender } \\
\hline Male & 60 & 45.8 \\
\hline Female & 71 & 54.2 \\
\hline \multicolumn{3}{|c|}{ Age } \\
\hline 25 or less & 6 & 4.6 \\
\hline $26-34$ & 50 & 38.2 \\
\hline $35-44$ & 39 & 29.8 \\
\hline 45-Over & 36 & 27.5 \\
\hline \multicolumn{3}{|c|}{ Race/Ethnicity } \\
\hline Malay & 30 & 22.9 \\
\hline Chinese & 8 & 6.1 \\
\hline Iban & 79 & 60.3 \\
\hline Bidayuh & 13 & 9.9 \\
\hline Others & 1 & 0.8 \\
\hline \multicolumn{3}{|c|}{ Qualification } \\
\hline Degree & 88 & 67.2 \\
\hline Diploma & 43 & 32.8 \\
\hline \multicolumn{3}{|c|}{ Years of Experiences } \\
\hline 1 year or less & 6 & 4.6 \\
\hline $1-5$ years & 24 & 18.3 \\
\hline $6-10$ years & 38 & 29.0 \\
\hline $11-15$ years & 27 & 20.6 \\
\hline 15 over & 36 & 27.5 \\
\hline \multicolumn{3}{|c|}{ Designation } \\
\hline Senior teacher & 21 & 16.0 \\
\hline Head of panel & 6 & 4.6 \\
\hline Subject teacher & 104 & 79.4 \\
\hline
\end{tabular}

\subsection{Collegial leadership, professional teacher behaviour, achievement press and institutional vulnerability}

Results shows (Table 2) that the r-values, alllinear relationships were positive and reached statistical significance except for two pair did not have significant relationship, professional teacher behavior and institutional vulnerability $(r=-0.026$, p-value $=0.765)$, achievement press and institutional vulnerability $(\mathrm{r}=0.087, \mathrm{p}$-value $=$ 
0.324). The significant bivariate relationships were identified between certain pairs such as collegial leadership and institutional vulnerability ( $\mathrm{r}=0.213$, $\mathrm{p}$-value $=0.014)$, professional teacher behaviour and collegial leadership $(r=0.233, \mathrm{p}$-value $=0.007)$, achievement press and collegial leadership ( $\mathrm{r}=$ 0.376, p-value $=0.000)$, achievement press and professional teacher behaviour $(\mathrm{r}=0.599$, $\mathrm{p}$-value $=$ 0.000). All the correlation is significant if the $\mathrm{p}<$ 0.05 .

Table 2: Correlation of institutional vulnerability, collegial leadership, professional teacher behaviour and achievement press

\begin{tabular}{|c|c|c|c|c|c|}
\hline \multicolumn{2}{|c|}{ Variables } & $\begin{array}{c}\text { Institutional } \\
\text { Vulnerability }\end{array}$ & $\begin{array}{c}\text { Collegial } \\
\text { Leadership }\end{array}$ & $\begin{array}{c}\text { Professional } \\
\text { Teacher Behaviour }\end{array}$ & $\begin{array}{l}\text { Achievement } \\
\text { Press }\end{array}$ \\
\hline \multirow{2}{*}{$\begin{array}{l}\text { Institutional } \\
\text { Vulnerability }\end{array}$} & $\begin{array}{l}\text { Pearson Correlation } \\
\text { Sig. (2-tailed) }\end{array}$ & 1 & & & \\
\hline & $\mathrm{N}$ & 131 & & & \\
\hline \multirow{3}{*}{$\begin{array}{l}\text { Collegial } \\
\text { Leadership }\end{array}$} & Pearson Correlation & $0.213^{*}$ & 1 & & \\
\hline & Sig. (2-tailed) & 0.014 & & & \\
\hline & $\mathrm{N}$ & 131 & 131 & & \\
\hline \multirow{3}{*}{$\begin{array}{l}\text { Professional } \\
\text { Teacher } \\
\text { Behaviour }\end{array}$} & Pearson Correlation & -0.026 & $0.233^{* *}$ & 1 & \\
\hline & Sig. (2-tailed) & 0.765 & 0.007 & & \\
\hline & $\mathrm{N}$ & 131 & 131 & 131 & \\
\hline \multirow{3}{*}{$\begin{array}{l}\text { Achievement } \\
\text { Press }\end{array}$} & Pearson Correlation & -0.087 & $0.376^{* *}$ & $0.599^{* *}$ & 1 \\
\hline & Sig. (2-tailed) & 0.324 & 0.000 & 0.000 & \\
\hline & $\mathrm{N}$ & 131 & 131 & 131 & 131 \\
\hline
\end{tabular}

\subsection{Collegial leadership, professional teacher behaviour, achievement press and institutional vulnerability and teachers' commitment}

The results (Table 3) of correlating the mean scores of the four total scores of collegial leadership, professional teacher behaviour, achievement press and institutional vulnerability with teachers' commitment. As indicated by the r-values, all-linear relationships were negative and not reached statistical significance except for one pair have significant relationship, achievement press and teachers commitment $(r=0.173, p$-value $=0.048)$. There are no significant bivariate relationships were identified between certain pairs such as collegial leadership and teachers commitment $(r=0.033$, $\mathrm{p}$ value $=0.710)$, institutional vulnerability and teachers commitment $(\mathrm{r}=-0.135, \mathrm{p}$-value $=0.124)$, professional teacher behaviour and teachers commitment $(\mathrm{r}=0.078, \mathrm{p}$-value $=0.378)$. All the correlation is significant if the $\mathrm{p}<0.05$.

Table 3: Correlation of institutional vulnerability, collegial leadership, professional teacher behaviour and achievement press

\begin{tabular}{|c|c|c|c|c|c|c|}
\hline \multicolumn{2}{|c|}{ Variables } & $\begin{array}{l}\text { Institutional } \\
\text { Vulnerability }\end{array}$ & $\begin{array}{c}\text { Collegial } \\
\text { Leadership }\end{array}$ & $\begin{array}{c}\text { Professional } \\
\text { Teacher Behaviour }\end{array}$ & $\begin{array}{c}\text { Achievement } \\
\text { Press } \\
\end{array}$ & $\begin{array}{c}\text { Teachers } \\
\text { Commitment }\end{array}$ \\
\hline $\begin{array}{l}\text { Institutional } \\
\text { Vulnerability }\end{array}$ & $\begin{array}{c}\text { Pearson Correlation } \\
\text { Sig. (2-tailed) } \\
\mathrm{N}\end{array}$ & $\begin{array}{c}1 \\
131\end{array}$ & & & & \\
\hline $\begin{array}{l}\text { Collegial } \\
\text { Leadership }\end{array}$ & $\begin{array}{c}\text { Pearson Correlation } \\
\text { Sig. (2-tailed) } \\
\text { N }\end{array}$ & $\begin{array}{c}0.213^{*} \\
0.014 \\
131\end{array}$ & $\begin{array}{c}1 \\
131\end{array}$ & & & \\
\hline $\begin{array}{l}\text { Professional } \\
\text { Teacher } \\
\text { Behaviour }\end{array}$ & $\begin{array}{c}\text { Pearson Correlation } \\
\text { Sig. (2-tailed) } \\
\text { N }\end{array}$ & $\begin{array}{c}-0.026 \\
0.765 \\
131\end{array}$ & $\begin{array}{c}0.233^{* *} \\
0.007 \\
131\end{array}$ & $\begin{array}{c}1 \\
131\end{array}$ & & \\
\hline $\begin{array}{l}\text { Achievement } \\
\text { Press }\end{array}$ & $\begin{array}{c}\text { Pearson Correlation } \\
\text { Sig. (2-tailed) } \\
\text { N }\end{array}$ & $\begin{array}{c}-0.087 \\
0.324 \\
131\end{array}$ & $\begin{array}{c}0.376^{* *} \\
0.000 \\
131\end{array}$ & $\begin{array}{c}0.599^{* *} \\
0.000 \\
131\end{array}$ & $\begin{array}{c}1 \\
131\end{array}$ & \\
\hline $\begin{array}{c}\text { Teachers } \\
\text { Commitment }\end{array}$ & $\begin{array}{c}\text { Pearson Correlation } \\
\text { Sig. (2-tailed) } \\
\text { N }\end{array}$ & $\begin{array}{c}-0.135 \\
0.124 \\
131\end{array}$ & $\begin{array}{c}0.033 \\
0.710 \\
131 \\
\end{array}$ & $\begin{array}{c}0.078 \\
0.378 \\
131 \\
\end{array}$ & $\begin{array}{c}0.173^{*} \\
0.048 \\
131\end{array}$ & $\begin{array}{c}1 \\
131 \\
\end{array}$ \\
\hline
\end{tabular}

\subsection{The relationship between school climate and teachers commitment}

R-Square is the proportion of variance in the dependent variables (Teachers Commitment) which can be predicted from the independent variables (achievement press, institutional vulnerability, collegial leadership and professional teacher behaviour). Table 4 shows the value of R-Square. This value indicates that only $5.5 \%$ variance in teachers commitment can be predicted from the variables of the achievement press, institutional vulnerability, collegial leadership and professional teacher behaviour.

As depicted in Table 5, there is no predictor variable was found. The coefficient values for all 
variables are more than the alpha value of 0.05 . All dimensions was no significant different. There is institutional vulnerability $(r=-0.349$, $\mathrm{p}$-value 0.084$)$, collegial leadership $(r=-0.007, \mathrm{p}$-value 0.963$)$, professional teacher behaviour ( $\mathrm{r}=-0.102$, $\mathrm{p}$-value $0.586)$ and achievement press ( $r=-0.455$, p-value $0.052)$.

Table 4: The regression between the variables

\begin{tabular}{|c|c|c|c|c|}
\hline Model & $\mathrm{R}$ & R Square & Adjusted R Square & Std. Error of the Estimate \\
\hline 1 & $0.234^{\mathrm{a}}$ & 0.055 & 0.025 & 0.78178 \\
\hline
\end{tabular}

This estimate informed the relationship between the independent variables and the dependent variable. These estimates told the amount increased in teachers' commitment scores that would be predicted by a 1 unit increased in the predictors. The standardized coefficient for achievement press was 0.224. Hence, for every unit increased in achievement, it was expected 0.224 point increased in the teacher's commitment scores. This is slightly statistically significant at $t=1.965, \mathrm{p}>0.05$. The beta coefficient value for institutional vulnerability was 0.155. Therefore, for every unit increased in institutional vulnerability, it was expected -0.155 point decrease in the teacher's commitment scores. This is not statistically significant at $\mathrm{t}=-1.740, \mathrm{p}>$ 0.05 . The beta coefficient value for collegial leadership was -0.004 . Therefore, for every unit in increased collegial leadership, it was expected -0.004 point in decrease the teacher's commitment scores. This is not statistically significant at $\mathrm{t}=-0.047, \mathrm{p}>$ 0.05 . The beta coefficient value for professional teacher behaviour was -0.059 . Therefore, for every unit in professional teacher behaviour increased, it was expected -0.059 point in decrease the teacher's commitment scores. This is not statistically significant at $\mathrm{t}=-0.545, \mathrm{p}>0.05$. From the regression analysis, the results showed that there is no predictor variable was found because the p-value of all dimension greater than 0.05. Table 5 indicated that achievement press, institutional vulnerability, collegial leadership and professional teacher behaviour dimension did not contribute to teachers commitment overall.

Table 5: Multiple regression analysis of collegial leadership, professional teacher behaviour, achievement press, institutional vulnerability and teacher commitment

\begin{tabular}{|c|c|c|c|c|c|}
\hline \multirow{2}{*}{ Variables } & \multicolumn{2}{|c|}{ Unstandardized Coefficients } & \multirow{2}{*}{$\begin{array}{c}\text { Standardized Coefficients } \\
\text { Beta } \\
\end{array}$} & \multirow{2}{*}{$\mathrm{t}$} & \multirow{2}{*}{ Sig. } \\
\hline & $\mathrm{B}$ & Std. Error & & & \\
\hline (Constant) & 2.754 & 0.933 & & 2.953 & 0.004 \\
\hline Institutional Vulnerability & -0.349 & 0.200 & -0.155 & -1.740 & 0.084 \\
\hline Collegial Leadership & -0.007 & 0.156 & -0.004 & -0.047 & 0.963 \\
\hline Professional Teacher Behaviour & -0.102 & 0.188 & -0.059 & -0.545 & 0.586 \\
\hline Achievement Press & 0.455 & 0.231 & 0.224 & 1.965 & 0.052 \\
\hline
\end{tabular}

Findings revealed that the levels of the four dimensions namely collegial leadership, professional teacher behaviour, achievement press and institutional vulnerability were at moderate or higher category. The perceptions of teacher respondents based on the four dimensions respectively collegial leadership, professional teacher behaviour and achievement press were mostly at the moderate to high level. However, four dimensions in the study did appear to demonstrate significant relationship except two pairs, professional teacher behavior dimension with institutional vulnerability dimension and achievement press with institutional vulnerability. Multiple regression analysis indicated that four dimension is not significant influence on teachers commitment.

\section{Conclusion and recommendations}

Finding from this study concluded that only one dimension of school climate was a predicator of commitment that is achievement press. Three of dimensions failed to be predicators of teacher's commitment. This shows that teachers are more likely to be committed to a school when they feel the help and care from other teachers. Collaboration can help teachers experience the rewards of teaching. Interaction with colleagues can give a sense of professionalism to help overcome a sense of isolationism and make a feeling that "we are all in this together." Teachers complete their jobs with a degree of enthusiasm. Teachers respect the professional competence of their colleagues and interact with other teachers. Committed teachers' workout professional judgement and "go the extra mile" for their students. Finally, the collective norm of the teacher culture influences commitment more than several of the other subtests especially collegial leadership. The results of this study suggest the need for further research on these and other related variables. Some logical expansions from this study given the importance placed on professional teacher's behavior are belief, enabling structure and teacher efficiency. A study might examine the role that beliefs play in school climate and teacher commitment. Though not measured in this study, one might predict that a healthy school climate with committed teachers must have some degree of belief. Another achievable study might look into the structure of various schools. A study could examine 
empowering or thoughtful school structures to see if they have higher levels of teacher's commitment.

\section{References}

Alig-Mielcarek JM (2003). A model of school success: Instructional leadership, academic press, and student achievement. Ph.D. Thesis, Ohio State University, USA.

Allen NJ and Meyer JP (1996). Affective, continuance, and normative commitment to the organization: An examination of construct validity. Journal of Vocational Behavior, 49(3): 252-276

Anderson JR (1982). Acquisition of cognitive skill. Psychological Review, 89(4): 369-406.

Bartlett L (2004). Expanding teacher work roles: A resource for retention or a recipe for overwork? Journal of Education Policy, 19(5): 565-582.

Firestone WA and Pennell JR (1993). Teacher commitment, working conditions, and differential incentive policies. Review of Educational Research, 63(4): 489-525.

Fredriksson U (2004). Studying the supra-national in education: GATS, education and teacher union policies. European Educational Research Journal, 3(2): 415-441.

Hallinger P and Heck RH (1998). Exploring the principal's contribution to school effectiveness: 1980-1995. School Effectiveness and School Improvement, 9(2): 157-191.

Halpin A and Croft D (1963). The organizational climate and individual value systems upon job satisfaction. Personnel Psychology, 22: 171-183.

Hausman CS and Goldring EB (2001). Sustaining teacher commitment: The role of professional communities. Peabody Journal of Education, 76(2): 30-51.

Hoy WK (2003). An analysis of enabling and mindful school structures: Some theoretical, research and practical considerations. Journal of Educational Administration, 41(1): 87-109.

Hoy WK and Woolfolk AE (1990). Socialization of student teachers. American Educational Research Journal, 27(2): 279. 300 .

Hoy WK, Gage CQ, and Tarter CJ (2006). School mindfulness and faculty trust: Necessary conditions for each other? Educational Administration Quarterly, 42(2): 236-255.

Hoy WK, Hannum JO, and Tschannen-Moran M (1998). Organizational climate and student achievement: A parsimonious and longitudinal view. Journal of School Leadership, 8(4): 336-359.

Hoy WK, Smith PA, and Sweetland SR (2002). The development of the organizational climate index for high schools: Its measure and relationship to faculty trust. The High School Journal, 86(2): 38-49.

Hoy WK, Tarter CJ, and Hoy AW (2006). Academic optimism of schools: A force for student achievement. American Educational Research Journal, 43(3): 425-446.
Hoy WK, Tarter CJ, and Kottkamp RB (1991). Open schools, healthy schools: Measuring organizational climate. Corwin Press, California, USA.

Joffres C and Haughey M (2001). Elementary teachers' commitment declines: Antecedents, processes, and outcomes. The Qualitative Report, 6(1): 1-22.

Leithwood K and McAdie P (2007). Teacher working conditions that matter. Education Canada, 47(2): 42-45.

Leithwood K, Seashore Louis K, Anderson S, and Wahlstrom K (2004). Executive summary: Review of research: How leadership influences student learning. University of Minnesota, USA.

Maslowski R (2001). School culture and school performance: An explorative study into the organizational culture of secondary schools and their effects. Twente University Press, Enschede, Netherlands.

Razak NA, Darmawan IG, and Keeves JP (2009). Teacher commitment. In: Lawrence JS and Dworkin AG (Eds.), International handbook of research on teachers and teaching: 343-360. Springer, New York, USA.

Riehl C and Sipple JW (1996). Making the most of time and talent: Secondary school organizational climates, teaching task environments, and teacher commitment. American Educational Research Journal, 33(4): 873-901.

Ross AZ and Normah CD (2011). Teacher stress: An examination of factors influencing teaching performance in the rural elementary schools. In the Simposium Sains Kesihatan Kebangsaan ke, 7: 224-225.

Singh K and Billingsley BS (1998). Professional support and its effects on teachers' commitment. The Journal of Educational Research, 91(4): 229-239.

Smith MC, Shakman K, Jong C, Terrell DG, Barnatt J, and McQuillan $P$ (2009). Good and just teaching: The case for social justice in teacher education. American Journal of Education, 115(3): 347-377.

Smith PA, Hoy WK, and Sweetland SR (2001). Organizational health of high schools and dimensions of faculty trust. Journal of School Leadership, 11(2): 135-151.

Stoddard C and Kuhn P (2008). Incentives and effort in the public sector: Have US education reforms increased teachers' work hours?. Economics of Education Review, 27(1): 1-3.

Sweeney J (1992). School climate: The key to excellence. NASSP Bulletin, 76(547): 69-73.

Williams J and Ritter JK (2010). Constructing new professional identities through self-study: From teacher to teacher educator. Professional Development in Education, 36(1-2): 77-92.

Witziers B, Bosker RJ, and Krüger ML (2003). Educational leadership and student achievement: The elusive search for an association. Educational Administration Quarterly, 39(3): $398-425$ 